\title{
Resenha do livro "Alucinações musicais: relatos sobre a música e o cérebro"
}

\author{
Book review of Musicophilia: Tales of Music and Brain
}

\section{Idonézia Collodel Benetti ${ }^{1}$}

\section{RESUMO}

Na obra "Alucinações musicais" Oliver Sacks, professor de neurologia Clínica na Columbia University, New York, relata casos de homens e mulheres que, em condições neurológicas raras, reagem à música de forma incomum: alguns não conseguem ouvi-la, e outros simplesmente ouvem música todo o tempo, mesmo sem nenhuma melodia tocando. Há descrição de casos em que, após um acidente, a pessoa desenvolve um talento musical que antes não existia. O livro oferece uma fascinante coletânea de fenômenos interligando neurologia, fisiologia e música, mostrando que a música pode sobreviver a danos cerebrais devastadores. Unitermos. Encéfalo, Música, Fisiologia, Dano Encefálico.

Citação. Benetti IC. Resenha do livro "Alucinações musicais: relatos sobre a música e o cérebro".

Unitermos. Fisioterapia (especialidade), Otorrinolaringopatias, Reabilitação, Vertigem.

Citação. Teixeira L, Prado GF. Impacto da fisioterapia no tratamento da vertigem.

Trabalho realizado na Universidade para o Desenvolvimento do Alto Vale do Itajaí, Alto Vale do Itajaí-SP, Brasil.

\section{SUMMARY}

In the book of "Musicophilia: Tales of Music and the Brain" Oliver Sacks, a Professor of Clinical Neurology at Columbia University in New York City, describes interesting stories about men and women with rare neurological conditions, which react to music in uncommon forms: some of them are unable to hear any kind of music and others, on the contrary, listen to music all the time, even when no melody is being typed. There are cases where, after an accident, the person involved develops a musical talent, that did not manifest before. The book offers a fascinating number of stories about phenomena linking neurology, physiology and music, showing that music can survive the most devastating brain damage.

Keywords. Brain, Music, Physiology, Brain Damage. Citation. Benetti IC. Book review of Musicophilia: Tales of Music and Brain.

1. Pianista, Psicóloga e Professora Msc da Universidade para o Desenvolvimento do Alto Vale do Itajaí, Alto Vale do Itajaí-SP, Brasil.

\author{
Endereço para correspondência: \\ Rua Bom Retiro, 212 \\ CEP 89160-000, Rio do Sul-SC \\ e-mail: idonezia@hotmail.com
}

Recebido em: 13/04/2009 Revisado em: 14/04/2009 a 18/08/2009

Aceito em: 19/08/2009

Conflito de interesses: não 
A música tem o poder de nos transportar para as "alturas" e/ou para as "profundidades" da emoção. Seu poder é eficaz em relembrar nosso primeiro encontro amoroso, em nos persuadir a comprar, em nos tornar alegres ou tristes, em nos oferecer prazer e paz. Mas esse poder vai muito mais além: na verdade, a música, dependendo da situação e da condição do ouvinte, pode representar momentos quase insuportáveis de irritação e tortura, provocar convulsões, como no caso de um paciente epilético do autor que tem convulsões quando ouve qualquer tipo de música e, por esta razão, anda com tampões de ouvido na cidade de Nova York. Mas a música também pode provocar o efeito contrário do alívio para o sintoma de certas doenças neurológicas.

São essas relações intrigantes do homem com a música, a maioria relacionada a alterações perceptivas e neurológicas, que são apresentadas na obra de Oliver Sacks ${ }^{1}$, neurologista reconhecido internacionalmente, traduzido para o português brasileiro por Laura Teixeira Motta, sob o título "Alucinações musicais: relatos sobre a música e o cérebro", do original em língua inglesa, "Musicophilia: Tales of Music and the Brain".

Obra lançada em outubro de 2007, pela Companhia da Letras em São Paulo, oferece ao leitor uma coletânea de casos clínicos comentados pelo Dr. Oliver, que se apresenta à literatura, com seu próprio gênero literário, oferecendo um material com as suas digitais. Seguindo seu toque distinto, ele escreve não apenas como médico e cientista, mas também como um humanista com tendências filosóficas. Neste sentido, ele é capaz de equalizar e conjugar duas áreas do conhecimento: neurociência médica e arte musical, passeando pelos mistérios do cérebro humano e pela profundidade e complexidade da música.

Sem dúvida, àqueles que apreciam os escritos de Sacks encontrarão, nesta obra, narrativas peculiares deste autor que continua um participante ativo em suas histórias clínicas; aqui ele mistura as experiências de seus pacientes com suas próprias experiências. Em um dos capítulos, o autor discute as alucinações musicais, incluindo o caso da própria mãe. Ele também relata seu caso de "amusia" adquirida. Assim, ele consegue a empatia do leitor, ao se revelar do outro lado do texto.

Ele divide esta publicação em quatro partes, a saber:

"Perseguidos pela música" - descreve casos de pacientes que reportam que há determinados fragmentos musicais que não saem da sua cabeça. Eles tentam deixar de ouvi-los, mas eles estão lá e eles não sabem o que fazer para se livrar deles; e a música continua tocando, descontrolada e repetitiva, atrapalhando as atividades cotidianas. Há narrações sobre: "musicofilia" obsessiva, que surge abruptamente logo após a um dano cerebral; epilepsia "musicogênica", onde determinadas músicas frequentemente "disparam" as crises convulsivas; epilepsia musical, onde as músicas fazem parte do conteúdo das convulsões; imagens evocadas pela música e "brainworms" (traduzido como "verme do cérebro", em linguagem popular: "minhoca na cabeça", mas aqui, a minhoca está relacionada à música), fragmentos musicais e imagens que continuamente insistem em "povoar" os pensamentos.

"A variação da musicalidade" - traz à tona os talentos e os cérebros musicais discutindo se há diferenças nos cérebros de músicos e não músicos; ouvido absoluto - a capacidade de identificar tonalidades sonoras fora do seu contexto; amusia e desarmonia; o ouvido imperfeito: amusia coclear; a sinestesia e a música.

"Memória, movimento e música" - discorre sobre o efeito da música sobre casos de amnésia retrógrada, memória emocional e preservação da memória musical, lesão cerebral, Parkinson, Tourette, membro fantasma, desordens do movimento - distonia do músico - relacionando a música como forma de tratamento.

"Emoção, identidade e música" - descreve os sonhos musicais, música e drogas psicodélicas, música e depressão, demência e musicoterapia, os aspectos musicais do autismo, emoções e música. Nesta sessão, fica enfatizada a importância da música, mostrando que ela pode se um recurso terapêutico para orientar um paciente quando mais nada é capaz de fazê-lo.

Resumindo, o livro contém 29 capítulos independentes, cada um falando sobre excessos e perdas relacionadas à música. Há relatos de pessoas que tem a capacidade de enxergar cores quando pensam em uma nota musical; de guardar sinfonias inteiras e até um vasto repertorio - os savants; de aprender novas partituras e de tocar e improvisar ao piano mesmo com perda severa de memória; de experimentar uma compulsão irresistível por ouvir música de piano, após ter sido atingido por um raio, e se tornar um pianista, mesmo sem talento musical e interesse por música; ouvir melo- 
dias, mas não distinguir os ritmos; ter alucinações musicais, como reação a uma surdez progressiva.

Os poderes terapêuticos da música vêm sendo "namorados" e acumulados pelo autor, ao longo de sua vida profissional. Ele tem presenciado pacientes que reagem bem ao ouvirem música, obtendo conforto para seu sofrimento, quando nenhuma medicação é capaz de fazê-lo. Esse flerte fica oficialmente deflagrado em sua obra "Tempo de despertar", onde ele descreve os efeitos surpreendentes da música nos seus pacientes.

Agora, ele dedica toda a presente obra a este assunto. E, como em obras anteriores, Sacks tenta disponibilizar o mundo da neurologia para os leigos deixando, na medida do possível, a linguagem científica para os trabalhos acadêmicos, usando linguagem leiga para se aproximar do leitor comum. Essa, talvez, seja a tônica de seu sucesso enquanto escritor e divulgador científico. Porém, conjugar duas áreas do conhecimento em uma só obra, tem seus percalços.
Não é tarefa simples encontrar um leitor com noções mínimas de Neurociências e Música ao mesmo tempo. Assim, apesar da tentativa de tornar o texto científico claro para o leitor leigo, há momentos em que as descrições técnicas podem parecer um tanto cansativa. Ainda assim, é um livro recomendado não somente para leigos, mas para todos aqueles profissionais de saúde e outros profissionais - médicos, psicólogos, musicoterapeutas, pessoas envolvidas com a área das neurociências - que sabem que o organismo humano é sensível à música, e este requisito pode ser usado multidisciplinarmente para fins terapêuticos.

Sem sombra de dúvidas, além de abrangente, o autor conseguiu mostrar que a música é capaz de "descongelar" as avenidas neurológicas devolvendo mobilidade, ritmo, fala e fluência, recobrando lembranças, controlando tiques e impulsos, enfim, devolvendo qualidade de vida.

\section{REFERÊNCIAS}

1.Sacks O. Alucinações Musicais. São Paulo: Companhia das Letras, 2007, 360 p. 